\title{
Estimation of near-surface attenuation in the tectonically complex contact area of the northwestern External Dinarides and the Adriatic foreland
}

\author{
Snježana Markušić ${ }^{1}$, Davor Stanko ${ }^{2}$, Tvrtko Korbar ${ }^{3}$, and Ivica Sović ${ }^{1}$ \\ ${ }^{1}$ Faculty of Science, University of Zagreb, Zagreb, Croatia \\ ${ }^{2}$ Faculty of Geotechnical Engineering, University of Zagreb, Varaždin, Croatia \\ ${ }^{3}$ Department of Geology, Croatian Geological Survey, Zagreb, Croatia
}

Correspondence: Snježana Markušić (markusic@irb.hr)

Received: 3 January 2019 - Discussion started: 8 March 2019

Revised: 28 August 2019 - Accepted: 28 October 2019 - Published: 3 December 2019

\begin{abstract}
Seismically induced ground motion at a site is generally influenced by the seismic source, the propagation path and the local site conditions. Over the last several decades, researchers have consistently asserted that for near-site attenuation, the spectral parameter $\kappa$ is subject primarily to the site conditions. In this research, we estimated the parameter $\kappa$ based on the acceleration amplitude spectrum of shear waves from local earthquakes recorded by seismological stations situated in the western part of Croatia from the slope of the high-frequency part. The spatial distribution of $\kappa$ values is comparable with seismological, geophysical and geological features, with the published coda- $Q$ values for each station as well as with the isoseismal maps for selected stronger earthquakes in the study area. The complex pattern of longitudinal and transversal major late-orogenic fault zones dissecting early-orogenic thin-skinned tectonic cover in the Kvarner area and the shallow depth to the Moho (Mohorovičić discontinuity) in the Adriatic foreland (southern Istria) are probably responsible for a significant part of wave attenuation and for the anisotropy of attenuation. Regional near-surface attenuation distribution and modelled macroseismic fields point to the conclusion that attenuation properties of rocks in the northwestern External Dinarides are far from isotropic, and the most likely anisotropy sources are the preferential orientations of cracks and fractures under the local tectonic stress field, trapping of waves along major faults (waveguides), and/or attenuation within the fault zones. These results are important for gaining further insight into the attenuation of near-surface crust layers in the northwestern External Dinar-
\end{abstract}

ides and the associated Adriatic foreland as well as in similar geotectonic settings.

\section{Introduction}

It is a well-known fact that earthquake shaking at the particular site in terms of observed or recorded strong ground motion is subject to complex source characteristics, attenuation of seismic waves when they propagate through the Earth's crust and changes resulting from local site conditions (e.g. Reiter, 1990).

Attenuation of seismic waves is a key factor in seismic hazard assessment for earthquake prone regions. It is also important for the quantification of earthquakes and plays a significant role in studies of seismic source or crustal structure.

This paper presents the calculated values of the highfrequency parameter $\kappa$ (Anderson and Hough, 1984) and the local site-specific component $\kappa_{0}$ (also called near-site or near-surface attenuation) in the area of northwestern External Dinarides and the respective Adriatic foreland based on recordings from four Croatian seismological stations. The area under research is shown in Figs. 1 and 2 and covers the region of Istria and part of the northern Adriatic offshore area (the Adriatic foreland) as well as the Kvarner islands, the wider area of Rijeka, the northern Dalmatian islands, and the regions of Lika and Gorski Kotar (the northwestern External Dinarides). 


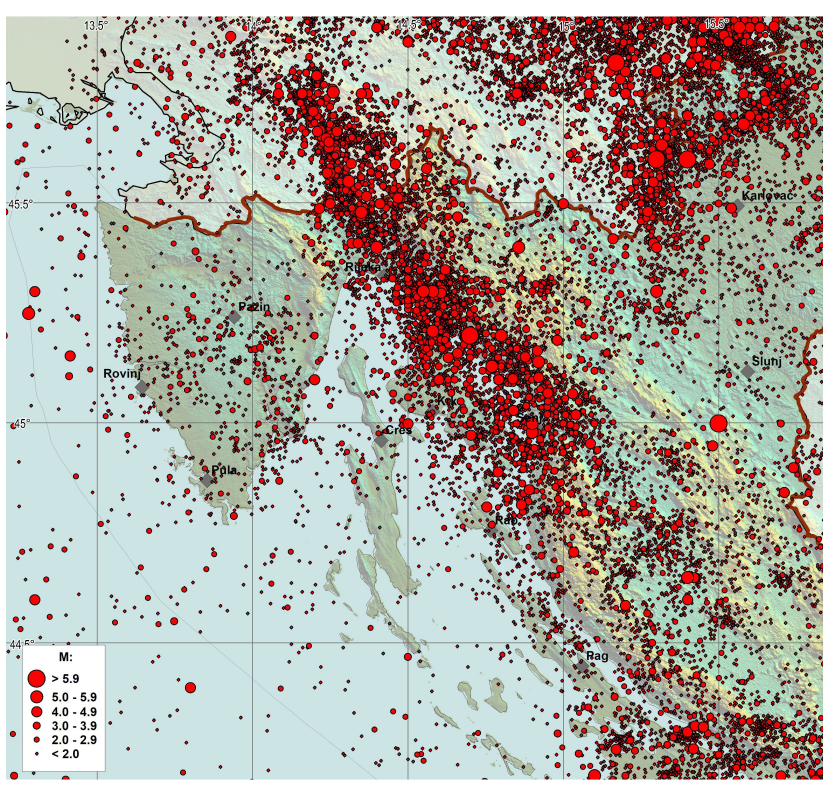

Figure 1. Spatial distribution of earthquake locations in the investigated area (373 BCE-2017 CE; according to the "Croatian Earthquake Catalog" - CEC; updated version first described in Herak et al., 1996). When preparing figure, Copernicus land dataset was used (C) European Union, Copernicus Land Monitoring Service 2017, European Environment Agency - EEA).

The major contribution to the seismic energy dissipation at sites and to the high-frequency part of the Fourier amplitude spectrum (FAS) of S waves (for which the near-site attenuation parameter $\kappa_{0}$ describes rapid decay) comes from the top surface layers to depths of 1-2 km (comprising sedimentary soils and rocks) and especially for close distances that are less than $50 \mathrm{~km}$.

The high-frequency attenuation parameter $\kappa$ is calculated from the slope of the FAS in the linear-logarithmic space for the high-frequency range of the S-wave window. Calculated individual horizontal $\kappa$ values for $\mathrm{E}-\mathrm{W}$ and $\mathrm{N}-\mathrm{S}$ components were combined to provide an average value of $\kappa_{\text {hor }}$ for each earthquake event. Using the Anderson and Hough (1984) approach, individual $\kappa$ values are paired with epicentral distances $R_{\mathrm{e}}$. For all analysed stations a gradual increase in $\kappa$ with epicentral distance $R_{\mathrm{e}}$ is observed.

Therefore, the $\kappa-R_{\mathrm{e}}$ model is used to estimate the value of the site-specific (near-site) attenuation parameter as a zero-distance $\kappa_{0}$ value. Over the last 3 decades, the nearsite attenuation parameter $\kappa_{0}$ has been regularly used in various applications, particularly in devising and calibrating ground-motion prediction equations (GMPEs), which are based on stochastic simulations (e.g. Hanks and McGuire, 1981; Boore, 1983, 2003; Ktenidou et al., 2014), host-totarget adjustments of GMPEs (e.g. Campbell, 2003; Biro and Renault, 2012; Delavaud et al., 2012) and site-specific ground response analysis for critical facilities. For $\kappa_{0}$, the term near-site attenuation is used given that it "captures" at-

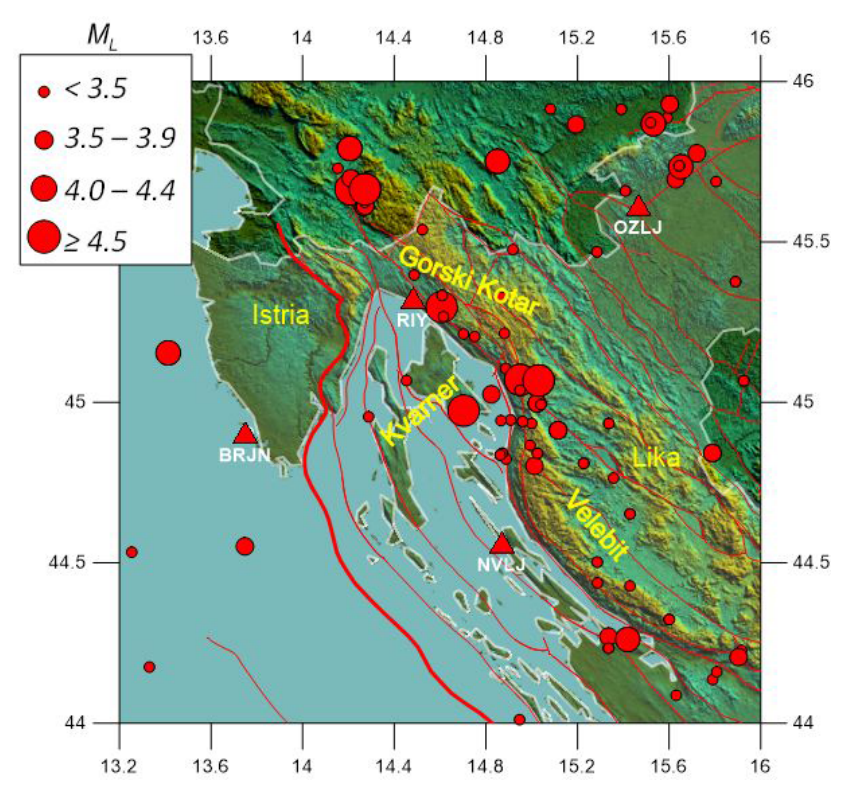

Figure 2. Topographic map of the study area with earthquake epicentres (2002-2016) used for $\kappa$ calculation. Red triangles mark the locations of seismic stations. Red lines represent possible seismogenic surface faults in Croatia (Ivančić et al., 2006). The thick red line designates frontal Dinaridic structures as well as the boundary between the External Dinarides and the Adriatic foreland. When preparing figure, Copernicus land dataset was used (ㄷ European Union, Copernicus Land Monitoring Service 2017, European Environment Agency - EEA).

tenuation effects near and below the site, i.e. within a radius of few kilometres around the site.

To address the effect of the uncertainty in $R_{\mathrm{e}}$ on the $\kappa$, instead of using the traditional linear least-squares regression, the linear regression suitable for data with errors, following the method by York et al. (2004), was performed.

Estimated regional and local variations in the spectral parameter $\kappa$ were compared with the geological characteristics of the investigated area and with macroseismic fields for selected earthquakes.

\section{Geological features and seismic activity}

The territory of Croatia is situated on the broad AfricaEurasia (central-northern Mediterranean) collision zone (Battaglia et al., 2004, and references therein). The Adriatic microplate (Adria) is situated in between the Nubian (Africa), Eurasian and Anatolian plates and probably moves as an independent microplate (Battaglia et al., 2004). The Adria dips to the northeast (NE) beneath the External Dinarides (Šumanovac et al., 2017), which could be considered to be the detached and back-thrust pre-orogenic upper sedimentary cover of the Adriatic microplate, deformed into a classical fold-and-thrust belt during the Alpine orogeny in the region (Schmid et al., 2008). The tectonic structure of 
the northeastern Adriatic region is subdivided into the Adriatic foreland and the External Dinarides, which are crustal megaunits developed atop the subducted Adriatic microplate during the Cenozoic (Korbar, 2009). The External Dinarides are characterized predominantly by the faults striking NW-SE along the eastern part of the Adriatic coast that is predominantly composed of Mesozoic shallow marine carbonate platform formations (Vlahović et al., 2005). Though parts of the northwestern and southeastern External Dinarides are characterized by obvious thin-skinned tectonics, resulting from strong tangential movements during the main phase of the Alpine (Dinaridic) orogeny (Schmid et al., 2008, and references therein), this tectonic feature is not that obvious in the investigated area of the External Dinarides (Korbar, 2009).

Earthquake hypocentres are distributed along the External Dinarides until a depth of $30 \mathrm{~km}$ (Prelogović et al., 1982; Kuk et al., 2000) and probably originate from recent tectonic activity along the complex transpressional zone striking NWSE, causing active uplift of the main crest of the External Dinarides (Korbar, 2009, and references therein). In addition to the tangential tectonic movements, responsible for significant deformations of the affected sedimentary cover, the neotectonic phase is characterized by a horizontal shearing of neighbouring tectonic units or blocks, especially along the re-activated NW-SE Dinaridic faults as well as along inferred transversal faults that have yet to be clearly described and investigated.

Upper-crustal geological structures are the result of tectonic movements in the deeper parts of the lithosphere which in turn feature deformations of the supposed basement of sediments and the Moho (Mohorovičić discontinuity), provided by gravimetric and seismic data from the area recorded during the 1960s, 1970s (Aljinović and Blašković, 1981; Aljinović et al., 1984), and later during the ALP 2002 and ALPASS-DIPS projects (Šumanovac, 2010; Šumanovac et al., 2009, 2016). The data imply a very coherent seismic reflector that is interpreted as "strong lithological changes occurring between Triassic carbonates and the underlying clastics" (Aljinović and Blašković, 1981) or the base carbonate (BC) reflector (cf. Grandić et al., 2002). The seismic data indicate that the basement of sediments in Istria and on the island of Krk has not been determined (Aljinović et al., 1984), however, with a remark that in Istria a reduced thickness of carbonate rock succession exists (Đurasek et al., 1981).

The BC is upthrown north of the northeastern Adriatic fault zone striking NW-SE generally along the mainland coast (Korbar, 2009) and crops out in the central part of Gorski Kotar (HGI, 2009). Besides this, the displacement of the BC is achieved along a transversal fault striking NESW at the eastern boundary of the Kvarner fault zone (Aljinović and Blašković, 1981). Nevertheless, regional geomorphology and detected tectonic lines generally correspond to the supposed and still tentatively defined Kvarner fault zone (Grandić et al., 2002; Finetti, 2005; Korbar, 2009).
The gravity map of Bouguer anomalies (Gravity map of Yugoslavia, 1972) exhibits a high coincidence with the spatial depth variation in the Mohorovičić discontinuity (e.g. Brückl et al., 2007; Orešković et al., 2011). Two facts are evident - the area of positive anomalies extending NW to SE with maxima in Istria and the stretch of negative anomalies following the axis along the deepest parts of the Mohorovičić discontinuity. Furthermore, the large zone of positive magnetic anomalies in Istria is evident but is not noticeable in either the gravity or Mohorovičić subsurface maps. The total intensity anomalies (Brdarević and Oluić, 1979) of the geomagnetic field indicate that only the deeper parts of the northern Adriatic are slightly magnetic. The crystalline basement of sedimentary rocks is supposed to be composed of slightly magnetic rocks from which the magnetic igneous rocks protruded during the geological evolution.

Local seismicity features are important, since besides local and regional attenuation as primary contributions to $\kappa$, orientation of the earthquake epicentres can have an effect on the $\kappa$ distribution. The investigated region is moderately seismically active (Fig. 1). Seismic activity in the greater Rijeka area is known for frequent occurrences of relatively weak earthquakes $\left(M_{\mathrm{L}}<4.0\right)$ and occasional occurrences of moderate or large ones (Ivančicć et al., 2006, 2018). The earthquake foci lie at depths of up to $20 \mathrm{~km}$, with the seismogenic tectonic zone striking in a NW-SE direction along the coastline. It is dominated by the Ilirska Bistrica-RijekaSenj obliquely reverse fault system, indicating compression of the Dinarides and an oblique subduction of the Adriatic microplate (Kuk et al., 2000; Palenik et al., 2019). Figure 3 depicts fault plane solutions of all earthquakes in Croatian source mechanism database (Archive of the Department of Geophysics, Faculty of Science, University of Zagreb) for the study area and event magnitudes $M_{\mathrm{w}} \geq 3.0$. Displayed are so-called beach balls (stereographic projection of the lower focal hemisphere). The figure shows predominant source mechanisms with right-lateral displacement, although many events indicate pure reverse faulting.

\section{Estimation of $\kappa$ parameter and connection to quality factor $Q$}

The Croatian weak motion (WM) seismological stations included in this study are as follows: Brijuni - BRJN, Rijeka - RIY, Novalja - NVLJ - and Ozalj - OZLJ, as shown by the red triangles in Fig. 2. The seismograms of earthquakes recorded at the stations in the period 2002-2017 with $M_{\mathrm{L}} \geq 3.0$ and $R_{\mathrm{e}} \leq 150 \mathrm{~km}$ and at focal depths of $h<30 \mathrm{~km}$ were collected. The locations of the earthquakes are shown in Fig. 2. The selection of the local magnitude and epicentral distance limit values plays a major role in calculating $\kappa$ (Anderson and Hough, 1984; Drouet et al., 2010; Ktenidou et al., 2013). The magnitude limit and epicentral distance limit were applied to the selected recordings $\left(M_{\mathrm{L}} \geq 3.0\right.$; 


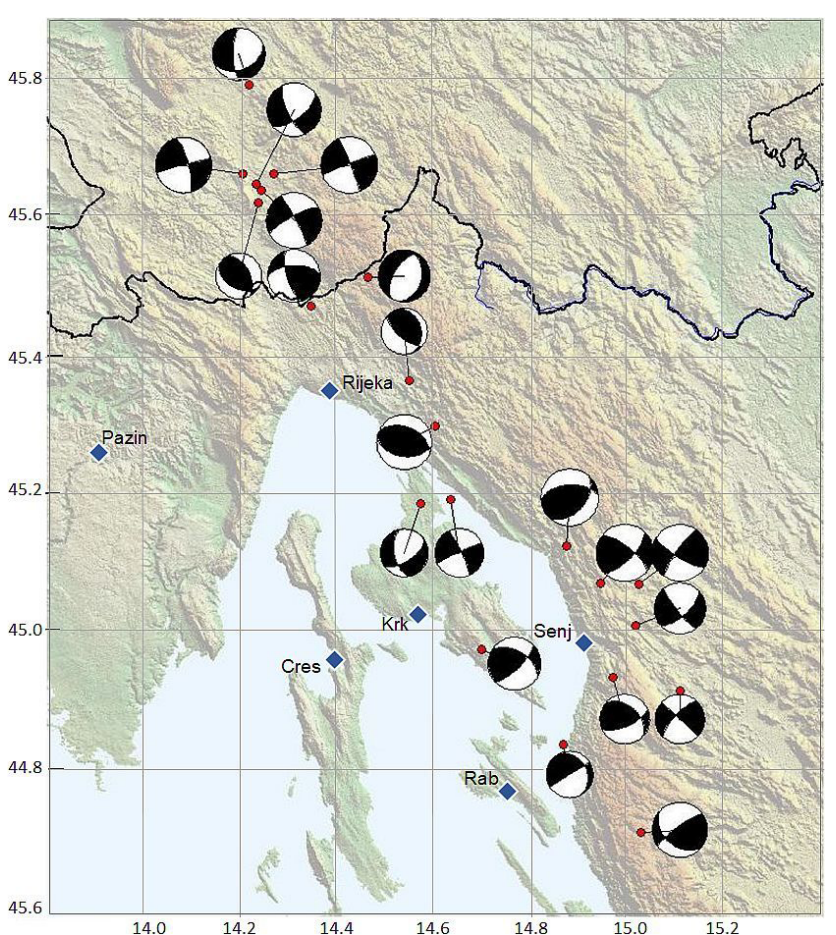

Figure 3. Focal mechanisms for regional earthquakes $\left(M_{\mathrm{W}} \geq 3.0\right)$ from the Croatian source mechanism database. Stereographic projection of the lower focal hemisphere was used. When preparing figure, Copernicus land dataset was used ( European Union, Copernicus Land Monitoring Service 2017, European Environment Agency - EEA).

$R_{\mathrm{e}} \leq 150 \mathrm{~km}$ ) in order to exclude possible source contribution to $\kappa$.

The azimuthal distribution of the used datasets was limited at each station due to the nature of earthquake locations and operative years of each station, as presented in Fig. 4 and Table 1.

As can be seen in Fig. 4 most of the earthquake recordings are in the magnitude range $3.0 \leq M_{\mathrm{L}} \leq 4.0$, with the earthquake locations distributed within $40 \leq R_{\mathrm{e}} \leq 100 \mathrm{~km}$. Station NVLJ recorded more than 100 earthquakes in the most seismically active parts of Croatia, and RIY recorded 60 earthquakes in moderate seismic areas, while BRJN (data only until the end of 2013) and OZLJ recorded around 3035 earthquakes (Table 1). As mentioned before, the number of recordings at each station depends not only on local seismicity but also on the operational period of each station.

The acceleration recordings were filtered using a bandpass filter at $0.5-25 \mathrm{~Hz}$ in order to exclude low-frequency noise. The dropout of the FAS at frequencies greater than $24 \mathrm{~Hz}$ was due to the anti-alias filter and did not affect the estimation of $\kappa$ from the slope of the high-frequency part of the FAS. The S-wave window with a minimum duration of $3 \mathrm{~s}$ (in some cases with part of coda waves which cannot be avoided) was selected for each record and processed using
Table 1. Number of analysed earthquakes and $V_{\mathrm{S} 30}$ for each station.

\begin{tabular}{lrrl}
\hline Station & Time period & $\begin{array}{r}\text { Number } \\
\text { of earthquakes }\end{array}$ & $\begin{array}{l}V_{\mathrm{S} 30} \\
\left(\mathrm{~m} \mathrm{~s}^{-1}\right)\end{array}$ \\
\hline BRJN & $2009-2013$ & 33 & EC8-A $^{*}$ \\
RIY & $2006-2016$ & 60 & $\approx 1190$ \\
NVLJ & $2002-2016$ & 107 & $\approx 1270$ \\
OZLJ & $2011-2016$ & 35 & $\approx 850$ \\
\hline
\end{tabular}

* Approximated as soil category A from EC8 due to the problem to obtain permit for geophysical survey in the Brijuni National Park (BRJN station).

the fast Fourier transform to obtain the FAS of the $S$ waves. In the preliminary spectrum processing, we follow signalto-noise-ratio (SNR) criteria (SNR > 3), as recommended by Ktenidou et al. (2013). Also, using the FAS of recordings that strongly deviate from exponential decay was avoided, i.e. a spectrum that increases in amplitude at higher frequencies due to combined effect of the site amplification between surface and deep bedrock and path-independent zero attenuation effects (Boore and Joyner, 1997) or a spectrum with the presence of strong resonance effects that corresponds to site fundamental and first higher harmonics (Ktenidou et al., 2013). The horizontal-to-vertical spectral-ratio (HVSR) curves recorded at the seismological stations were used as an indicator of possible strong resonance peaks at local sites which may have had an impact on estimating $\kappa$ from the FAS. The HVSR methodology proposed by Nakamura (1989) has been used in numerous studies to estimate local seismic ground response as expressed by natural or fundamental frequency $\left(f_{\text {res }}\right)$ of soils and HVSR spectral peak amplification, particularly in the broader study area, e.g. in Slovenia (Gosar, 2007; Gosar and Martinec, 2009; Gosar et al., 2010), in Italy (Mucciarelli and Gallipoli, 2001; Di Giacomo et al., 2005; Del Monaco et al., 2013; Panzera et al., 2013) and in Croatia (Herak et al., 2010; Herak, 2011; Stanko et al., 2016, 2017).

Geological and tectonic characteristics around each station (in the vicinity of approximately $30 \mathrm{~km}$ ) are important when defining primary factors affecting the $\kappa$ distribution. For that purpose, local and regional geological and tectonic characteristics are analysed and discussed based on the "Explanatory notes for the Geological Map of the Republic of Croatia" (Velić and Vlahović, 2009) and the cited papers. It should be noted that all the stations are situated on the hard bedrock without any superficial deposits or significant soil.

The Brijuni seismological station (BRJN) is situated on the island of Veliki Brijun (at an altitude of $22 \mathrm{~m}$ ) within the Brijuni National Park, i.e. on the western coast of the Istrian Peninsula. The wider area is characterized by a slightly deformed $2000 \mathrm{~m}$ thick low-fractured succession of Jurassic to Upper Cretaceous shallow-water carbonates deposited on top of the Adriatic carbonate platform (Vlahović et al., 2005). The tectonic structure of the area around the station is very simple and belongs to the Adriatic foreland (Korbar, 2009). 

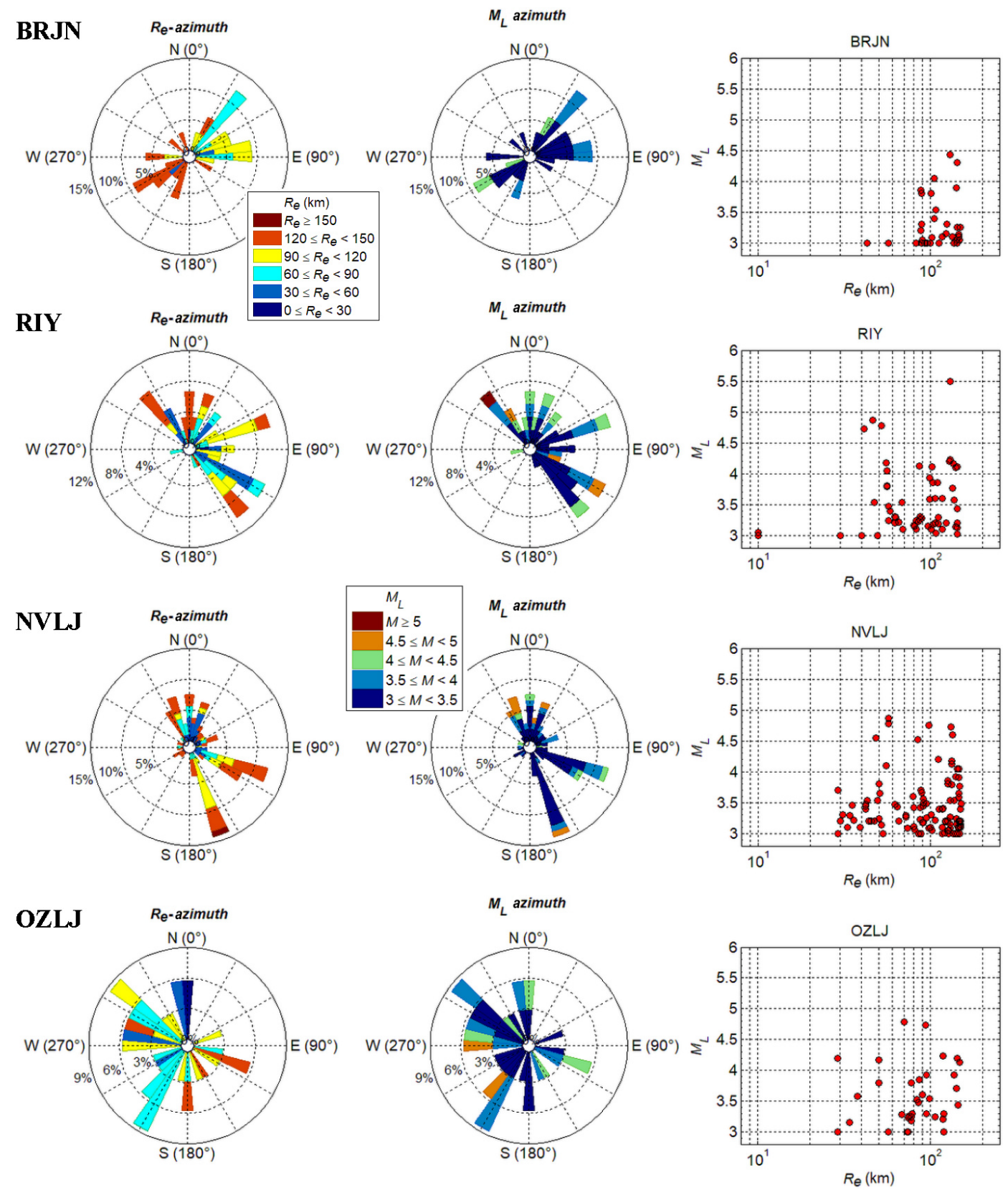

Figure 4. Statistics of the compiled ground-motion dataset. Left panels: azimuthal distribution of $R_{\mathrm{e}}$. Middle panels: azimuthal distribution of $M_{\mathrm{L}}$. Right panels: $R_{\mathrm{e}}-M_{\mathrm{L}}$ distribution of recordings at each station.

The carbonate strata are gently inclined to the southeast in the southeast limb of wide regional foreland anticline characterized by the axis striking SW-NE along central Istria.

The wider area around the seismological station $\mathrm{Ri}$ jeka (RIY) is mainly composed of strongly deformed and fractured Upper Cretaceous to Paleogene carbonates that have been strongly affected by an early-orogenic thinskinned tectonics (Korbar, 2009). Eocene flysch clastics are situated in the long synclines compressed between huge carbonate anticlines. The RIY station (at an altitude of $70 \mathrm{~m}$ ) is situated in Rijeka on Lower Cretaceous deposits consisting of limestones and dolomites that are approximately 500 $600 \mathrm{~m}$ thick. The overall thickness of the thin-skinned sedimentary cover cannot easily be estimated due to the lack of boreholes as well as due to a complex tectonic structure in the area. However, in the deep borehole located in the central part of the neighbouring island of Krk, carbonates are more than $3500 \mathrm{~m}$ thick, while the supposed thin-skinned, highly fractured part is at least $1500 \mathrm{~m}$ thick (Korbar, 2009). 
Table 2. Summarized results of errors-in-variables regression (following the method by York et al., 2004) for $\kappa-R_{\mathrm{e}}$ dependence based on horizontal- and vertical-component $\kappa$ models $(\kappa$ hor and $\kappa_{\mathrm{ver}}$ ) using the AH84 model. Site-specific (near-site) attenuation values $\kappa_{0}^{\text {hor }}$ and $\kappa_{0}^{\mathrm{ver}}$, slopes of regression in terms of $\kappa_{\mathrm{R}}^{\text {hor }}$ and $\kappa_{\mathrm{R}}^{\mathrm{ver}}$, standard errors for intercepts, and slopes and ratios of $\kappa_{0}^{\mathrm{ver}} / \kappa_{0}^{\text {hor }}$ and $\kappa_{\mathrm{R}}^{\mathrm{ver}} / \kappa_{\mathrm{R}}^{\text {hor }}$ are listed for each seismological station. Standard errors (SEs) for the intercept and slope are also listed (not bolded).

\begin{tabular}{lrrrr}
\hline & BRJN & RIY & NVLJ & OZLJ \\
\hline$\kappa_{\mathbf{0}}^{\text {hor }}(\mathbf{s})$ & $\mathbf{0 . 0 2 4 9}$ & $\mathbf{0 . 0 2 3 9}$ & $\mathbf{0 . 0 2 3 5}$ & $\mathbf{0 . 0 3 7 7}$ \\
$\mathrm{SE}-\kappa_{0}^{\text {hor }}(\mathrm{s})$ & 0.0045 & 0.0024 & 0.0020 & 0.0024 \\
$\kappa_{\mathbf{R}}^{\text {hor }}\left(\mathbf{s ~ k m}^{-\mathbf{1}}\right)$ & $\mathbf{0 . 0 0 0 1 3 1}$ & $\mathbf{0 . 0 0 0 1 9 6}$ & $\mathbf{0 . 0 0 0 1 7 2}$ & $\mathbf{0 . 0 0 0 2 3 7}$ \\
$\mathrm{SE}-\kappa_{\mathrm{R}}^{\text {hor }}\left(\mathrm{s} \mathrm{km}^{-1}\right)$ & 0.000039 & 0.000025 & 0.000019 & 0.000042 \\
$\kappa_{\mathbf{0}}^{\text {ver }}(\mathbf{s})$ & $\mathbf{0 . 0 3 6 2}$ & $\mathbf{0 . 0 2 1 2}$ & $\mathbf{0 . 0 2 2 5}$ & $\mathbf{0 . 0 4 1 2}$ \\
$\mathrm{SE}-\kappa_{0}^{\text {ver }}(\mathrm{s})$ & 0.0054 & 0.0031 & 0.0027 & 0.0040 \\
$\kappa_{\mathbf{R}}^{\text {ver }}\left(\mathbf{s ~ k m}^{-1}\right)$ & $\mathbf{0 . 0 0 0 1 1 0}$ & $\mathbf{0 . 0 0 0 2 1 9}$ & $\mathbf{0 . 0 0 0 1 5 2}$ & $\mathbf{0 . 0 0 0 2 0 4}$ \\
$\mathrm{SE}-\kappa_{\mathrm{R}}^{\text {ver }}(\mathrm{s} \mathrm{km}$ \\
$\kappa_{\mathbf{0}}^{\text {ver }} / \kappa_{\mathbf{0}}^{\text {hor }}$ & 0.000047 & 0.000032 & 0.000026 & 0.000043 \\
$\kappa_{\mathbf{R}}^{\text {ver }} / \kappa_{\mathbf{R}}^{\text {hor }}$ & $\mathbf{1 . 4 5}$ & $\mathbf{0 . 8 9}$ & $\mathbf{0 . 9 6}$ & $\mathbf{1 . 0 9}$ \\
\hline
\end{tabular}

The wider area of the Novalja seismological station (NVLJ), situated on the Pag Island, consists of intensely fractured Upper Cretaceous to Paleogene carbonates in long anticlines, which in the crestal parts consist of limestone breccia deposited in the axial zones. Flysch clastics are situated in the synclines, similar to those in the Rijeka area, given that both areas belong to the thin-skinned sedimentary cover. The NVLJ seismological station (altitude $10 \mathrm{~m}$ ) is situated in Novalja on Pag Island within the area mainly composed of limestone breccia of unknown thickness, while the modelled thin-skinned carbonates are up to a few thousand metres thick (Korbar, 2009).

The Ozalj station (OZLJ) is situated in the transition zone between the Dinarides and the Pannonian Basin, in a zone consisting mainly of deepwater carbonates and clastics that are covered by thin alluvium along the Kupa River valley. The wider area of the Ozalj seismological station (OZLJ) paleogeographically belongs to a carbonate platform-to-basin transition, which is in its recent structural position tectonically roughly equal to a front of a major overthrust with a southwestern vergence. The station itself is situated on the cliff hillside of the Kupa River (at an altitude of $186 \mathrm{~m}$ ) and is composed of deformed Upper Cretaceous flysch succession that is approximately $400-500 \mathrm{~m}$ thick and transgressively overlies the strongly fractured older carbonates.

In order to estimate the value of the site-specific (near-site) attenuation parameter $\kappa_{0}, \kappa$ models as a function of epicentral distance are proposed using the Anderson and Hough (1984) approach. Instead of using traditional linear least-square regression, linear regression for data containing errors and following the method by York et al. (2004) was applied to identify possible correlation for observational errors in two coordinates $\left(R_{\mathrm{e}}\right.$ and $\left.\kappa\right)$. Typically, the standard error for $R_{\mathrm{e}}$
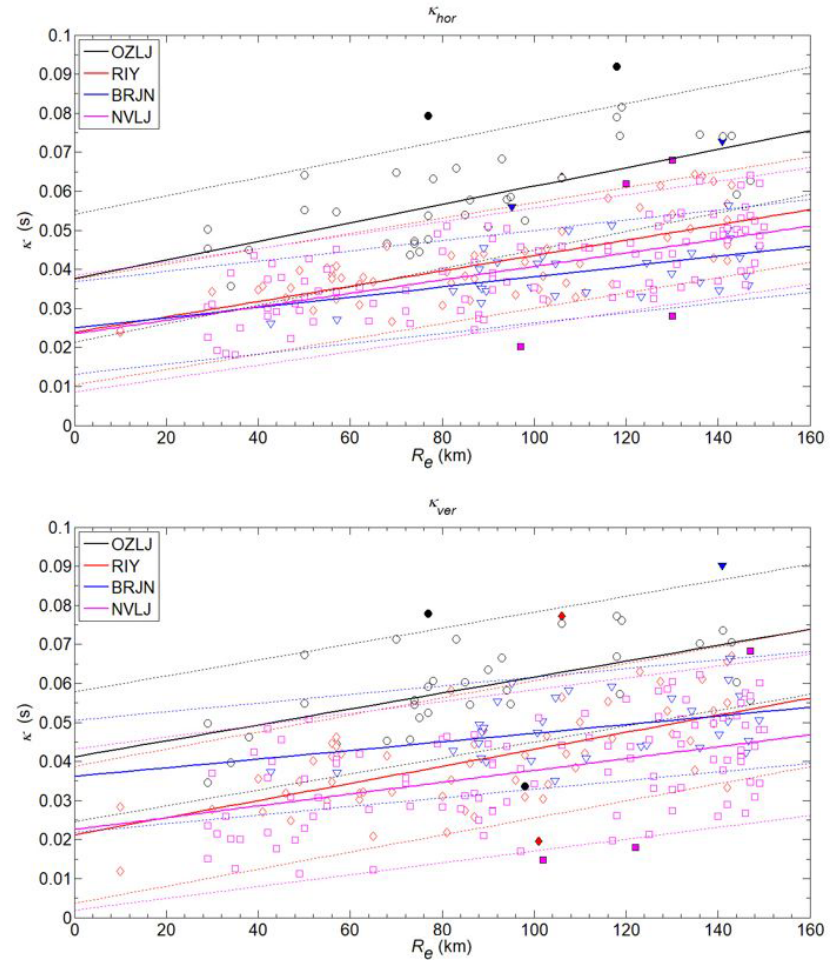

Figure 5. Horizontal and vertical $\kappa-R_{\mathrm{e}}$ models for each seismological station. Site-specific attenuation values of $\kappa_{0}^{\text {hor,ver }}$ (intercept at zero distance $R_{\mathrm{e}}$ ) and regression slopes $\kappa_{\mathrm{R}}^{\text {hor,ver }}$ are given in Table 2. Full markers are regression outliers outside of a $95 \%$ confidence interval (dashed lines).

amounts to $\pm 3-5 \mathrm{~km}$ (Marijan Herak, personal communication), and for these particular cases, with error in $\kappa$ set to 2 SD (standard deviation; $\sim 0.01-0.02 \mathrm{~s}$ ), differences between standard linear regression and error-in-variables linear regression are less than $5 \%$. With fewer data, large data scatter and a lack of data at shorter epicentral distances, differences between two regression methods could be significant. Therefore, for shorter epicentral distances, we set errors to be of the order of $5 \mathrm{~km}$, while for higher distances $(>100 \mathrm{~km})$, we set it to be $10 \mathrm{~km}$. The summarized results of errors-invariables regressions (following the method by York et al., 2004) for the $\kappa-R_{\mathrm{e}}$ dependence based on horizontal and vertical $\kappa$ models $\left(\kappa_{\text {hor }}\right.$ and $\kappa_{\text {ver }}$ ) using the AH84 (Anderson and Hough, 1984) approach are shown in Fig. 5 and given in Table 2 with estimated site-specific attenuation values of $\kappa_{0}^{\text {hor }}$ and $\kappa_{0}^{\mathrm{ver}}$ and regression slopes $\kappa_{\mathrm{R}}^{\text {hor }}$ and $\kappa_{\mathrm{R}}^{\mathrm{ver}}$ for each seismological station.

The slopes of regression lines, $\kappa_{\mathrm{R}}$ (Fig. 5 and Table 2), indicate a gradual increase in $\kappa$ with the epicentral distance $R_{\mathrm{e}}$ for all stations, consistent with the findings of Anderson and Hough (1984) and Ktenidou et al. (2013, 2015). The large scatter of data points is typical in $\kappa$ studies, as reported in the cited literature. Nearby recordings can constrain the site-specific $\kappa_{0}$, and distant recordings can constrain propa- 
gation path effects through the slope of regression $\kappa_{\mathrm{R}}$. Numerous researchers studying $\kappa$ have reported that a gradual increase may begin at distances of $15-20 \mathrm{~km}$, hence implying a regional attenuation effect in the Earth's crust, whereas the mean $\kappa$ values are somewhat constant (similar to the site-specific $\left.\kappa_{0}\right)$ at short distances. This effect seems to be true mainly due to limited data for shorter epicentral distances. The main attenuation contribution in $\kappa_{0}$ is due to the local site effects of the shallow crust near and below the site (up to depths of $1-2 \mathrm{~km}$ ), as reported by Van Houtte et al. (2011) and Ktenidou et al. (2015). This is the reason why $\kappa$ researchers use several terms (near-site attenuation, sitespecific attenuation or simply site attenuation) to describe the $\kappa_{0}$ parameter at zero distance or at short epicentral distances. The values of site parameter $V_{\mathrm{s} 30}$ (average shear wave velocity in the top $30 \mathrm{~m}$ of soil) that is correlated with local geological characteristics of each station can be compared to the estimated site-specific attenuation $\kappa_{0}$ values and, based on Tables 1 and 2, indicate that these two values are inversely proportional (Ktenidou et al., 2014).

Figure 6 shows a spatial regional $\kappa$ variation in the investigated area around each station (individual $\kappa$ values are plotted using the nearest-neighbour interpolation method). Different trends of high-frequency attenuation between northeastern and southwestern azimuthal area subsets can be observed. Based on the observations, one possible explanation is that the weaker or higher attenuation expressed in the regional $\kappa$ variations results from a large dispersion in individual $\kappa$ estimates at the near-fault zones and is related to $\mathrm{S}$-wave reflections. The spatial $\kappa$ distribution presented in Fig. 6 shows that attenuation properties of rocks in the northwestern External Dinarides are far from isotropic. The source of this anisotropy is still not confidently determined - the most likely candidates are the preferential orientations of cracks and fractures under the local tectonic stress field, trapping of waves along major faults (waveguides), or attenuation within the fault zones, which is discussed in more detail in the next section.

It is possible that large regional discrepancies in the values of $\kappa_{0}$ exist for similar sites due to regional differences of the underlying crustal $Q$ and $V_{\mathrm{S}}$ profile for similar $V_{\mathrm{S} 30}$ values (e.g. Boore and Joyner, 1997; Chandler et al., 2005). The conclusions should be drawn with caution due to the limited number of data at shorter distances and the narrow azimuthal datasets (Fig. 4). This is a major limitation when using Anderson and Hough's (1984) classical $\kappa$ approach to areas of low-to-moderate seismicity and is due to the limited quantity and bandwidth of usable data. Even if the trend of $\kappa$ with distance is clearly visible for all cases, more data that will be collected in the future may provide more evidence and resolution for the shortest distances, especially for stations where the lack of data is most prominent.

The high-frequency spectral attenuation parameter $\kappa$ was calculated from the acceleration FAS of the $S$ waves under the assumption that the effective quality factor $Q$ in

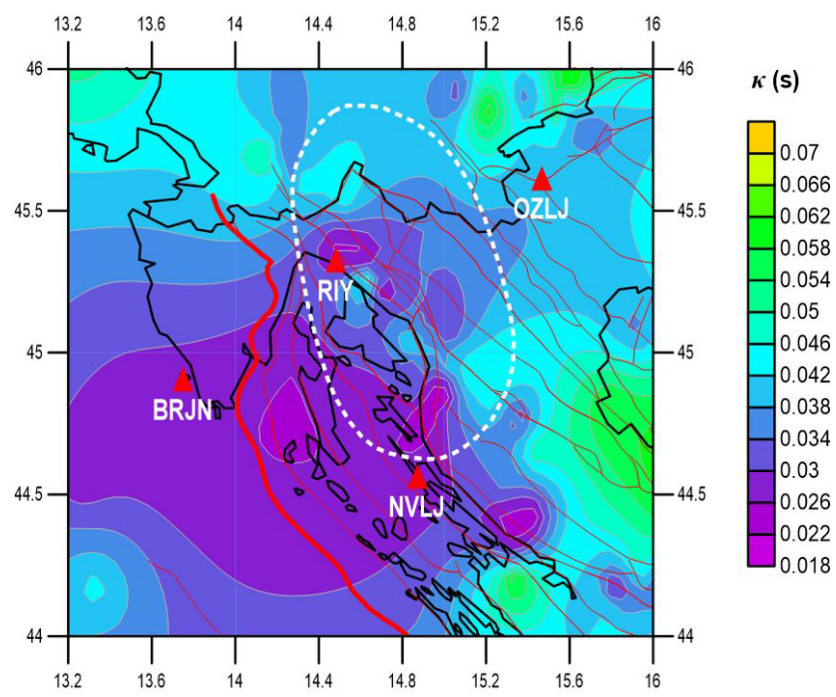

Figure 6. Regional $\kappa$ dependence around each seismological station shown as a spatial distribution of individual $\kappa$ values and plotted using the nearest-neighbour interpolation method. The red lines represent the possible seismogenic surface faults in Croatia as well as Bosnia and Herzegovina (Ivančić et al., 2006). The locations of the seismic stations are marked with red triangles. A thick white dashed line marks the contours of the northern Dinaric (ND) fast-velocity anomaly (Šumanovac and Dudjak, 2016). The thick red line marks the boundary between the External Dinarides (NE) and the Adriatic foreland (SW).

near-surface rocks (at approximately depths of up to 2 $3 \mathrm{~km}$ ) is frequency-independent. In this case, the frequencyindependent effective quality factor $Q_{\text {est }}$ at high frequencies can be estimated from the regression slope of the empirical model, $\kappa_{\mathrm{R}}$ (e.g. Anderson and Hough, 1984; Edwards et al., 2011; Gentili and Franceschina, 2011; Ktenidou et al., 2015):

$Q_{\text {est }}\left(\kappa_{\mathrm{R}}\right) \approx \frac{1}{\beta_{0} \kappa_{\mathrm{R}}}$,

where the average crustal shear wave velocity was assumed to be $\beta_{0}=3.5 \mathrm{~km} \mathrm{~s}^{-1}$. The ratio of the slopes $\kappa_{\mathrm{R}}$ for horizontal and vertical components are similar, i.e. approximately 1 (see Table 2). Therefore, only the horizontal value of $\kappa$ is used for the spatial $\kappa$ distribution and estimated $Q$ values, $Q_{\text {est }}\left(\kappa_{\mathrm{R}}\right)$, when describing regional attenuation.

Several studies indicated the possibility that $Q_{\text {est }}^{\mathrm{C}, \mathrm{S}}(f)$ from the coda waves (or $S$ waves) estimated for the highfrequency range and $Q_{\text {est }}\left(\kappa_{\mathrm{R}}\right)$ calculated from $\kappa_{\mathrm{R}}$ yield approximately similar values (e.g. Edwards et al., 2011; Gentili and Franceschina, 2011; Ktenidou et al., 2013, 2015). Table 3 compares the estimated values of frequencydependent $Q_{\text {est }}^{\mathrm{C}}$ (for the high-frequency range, $10-25 \mathrm{~Hz}$ ) from recent attenuation studies of coda waves in Croatia (Dasović et al., 2012, 2013; Dasović, 2015) with the frequency-independent $Q_{\text {est }}\left(\kappa_{\mathrm{R}}\right)$ from this study. Taking into account inherent errors of $Q$ and $\kappa$ measurements, the corresponding values for the Croatian station given in Table 3 
Table 3. Values of $Q_{0}^{\mathrm{C}}$ and $n_{\mathrm{C}}$ for the elapsed time of the coda wave window $t_{\mathrm{L}}=30 \mathrm{~s}$ (Dasović, 2015 - most recent values), $Q_{\mathrm{est}}^{\mathrm{C}}$ estimated for the high-frequency range $(10-25 \mathrm{~Hz})$ from $Q_{\text {est }}^{\mathrm{C}}(f)=$ $Q_{0}^{\mathrm{C}} f_{\mathrm{C}}^{n}$ and frequency-independent $Q_{\mathrm{es}} \kappa_{\mathrm{R}}$. There is no published information for the BRJN station regarding the existence of the frequency-dependent $(f)$.

\begin{tabular}{lcclcc}
\hline Station & $Q_{0}^{\mathrm{C}}$ & $n_{\mathrm{C}}$ & $\begin{array}{l}Q_{\text {est }}^{\mathrm{C}} \\
(10-25 \mathrm{~Hz})\end{array}$ & $\begin{array}{c}\kappa_{\mathrm{R}} \\
\left(\mathrm{s} \mathrm{km}^{-1}\right)\end{array}$ & $\begin{array}{c}Q_{\text {est }} \\
\left(\kappa_{\mathrm{R}}\right)\end{array}$ \\
\hline BRJN & - & - & - & 0.000131 & 2181 \\
RIY & 84 & 0.93 & $715-1362$ & 0.000196 & 1458 \\
NVLJ & 89 & 1.16 & $1286-2875$ & 0.000172 & 1661 \\
OZLJ & 78 & 0.69 & $382-616$ & 0.000237 & 1206 \\
\hline
\end{tabular}

show that this is mostly also the case here. This comparison helps to verify the accuracy of the regression slope $\kappa_{\mathrm{R}}$ from the $\kappa-R_{\mathrm{e}}$ models, but it also includes certain complexities (e.g. different data ranges for magnitudes and epicentral distances, the impact of frequency-dependent scattering attenuation and frequency-independent intrinsic attenuation having an effect on the $\kappa$ value). Taking into consideration the issues enumerated above, the results presented in Table 3, as well as similar conclusions of other studies, hint to the conclusion that the high-frequency decay of FAS, as modelled by $\kappa$, has its roots in anelastic (intrinsic) and scattering attenuation properties of the rocks along the path from the source to the receiver. Moreover, it may be possible that similar sites exhibit significantly large regional differences due to the variability in the underlying $Q$ and $V_{\mathrm{S}}$ structures (e.g. Boore and Joyner, 1997; Chandler et al., 2005; Ktenidou et al., 2014). Keeping all this in mind, $Q$ values calculated from coda waves and $\kappa$ values (Table 3 ) are considered comparable, while taking into account inherent errors of $Q$ and $\kappa$ measurements (often of the order of $\pm 50 \%$ ).

The values of $Q_{\text {est }}\left(\kappa_{\mathrm{R}}\right)$ (Table 3 ) that actually represent the total average regional crustal attenuation in the vicinity of each station may be linked to major tectonic units. Hence, the value of $Q_{\text {est }}\left(\kappa_{\mathrm{R}}\right)$ for the OZLJ station may represent a transitional zone between the Pannonian Basin and the Internal Dinarides (e.g. Tomljenović et al., 2008). In addition, the values of $Q_{\text {est }}\left(\kappa_{\mathrm{R}}\right)$ may define the transition zone from the undeformed Adriatic microplate (the BRJN station) into the deformed part of the Dinarides (the RIY and NVLJ stations; e.g. Handy et al., 2015). The value given in Table 3 for the BRJN station is comparable to the average value determined for crustal depths varying from 5 to $15 \mathrm{~km}$ and which were published by Gentili and Franceschina (2011) for the area of the southeastern Alps and northern External Dinarides in northeastern Italy (Friuli Venezia Giulia).

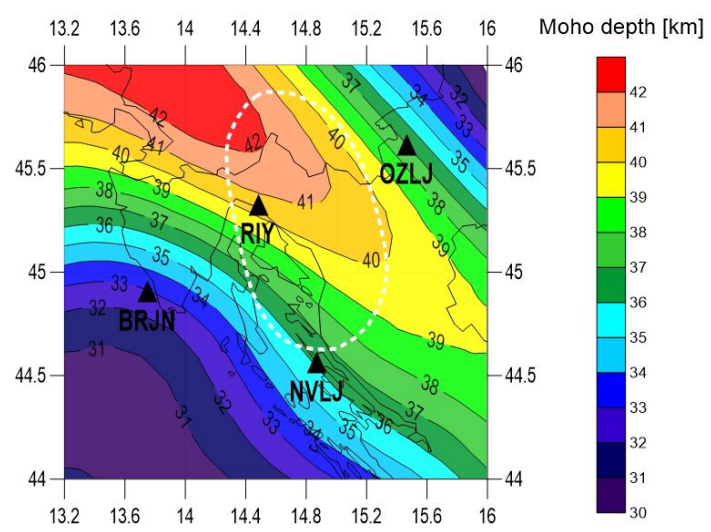

Figure 7. The Moho depth (Grad et al., 2009) at the study area. A thick white dashed line marks the contours of the northern Dinaridic fast-velocity anomaly determined by the teleseismic tomography (ND anomaly; Šumanovac and Dudjak, 2016).

\section{Discussion of the parameter $\kappa$ within regional seismological and geological characteristics}

The attenuation is possibly related to a highly fractured thinskinned tectonic cover in the hanging wall of the frontal Dinaridic thrust that differs from the less fractured carbonates below the major detachments (e.g. southern part of Gorski Kotar and central part of Velebit) as well as from the less fractured carbonates in the Adriatic foreland. It must be noted that the uppermost detachment horizon (major thrust faults) appears on the surface along the demarcation line between Gorski Kotar and the Kvarner area, as well as all around the main crest of Velebit (Korbar, 2009). The horizon is irregularly distributed within the investigated region due to the late-orogenic exhumation of the Dinarides and still insufficiently defined regional dextral shift of the frontal thrust of the External Dinarides along the Kvarner fault zone (Grandić et al., 2002; Korbar, 2009; Aljinović and Blašković, 1981). The dextral shift along the Kvarner fault zone was also detected in deep seismic images on the crustal scale (Finetti, 2005).

Weaker attenuation properties (see Fig. 6) may also be caused by S-wave reflection from different parts of the shallower Mohorovičić discontinuity (see Fig. 7), at a depth of about 25-30 km (e.g. Gentili and Franceschina, 2011). This is exactly the case for the Adriatic foreland part along the southwestern coast of Istria, where the Mohorovičić discontinuity depths vary from about $27 \mathrm{~km}$ (Finetti, 2005) to approximately $40 \mathrm{~km}$ (Brückl et al., 2007; Grad et al., 2009). These effects can be explained by observations that fault zones are often characterized by complex rupture patterns that favour both scattering and generation of trapped waves (within the waveguides) in terms of 10-20 km propagation through low velocity and spatial variation in low intrinsic $Q_{\mathrm{i}}$ near the source, caused by the high level of fracturing that characterizes the fault zones. 
Several authors have analysed attenuation in carbonates that were modified by tectonic processes (fractured) and those not modified. Johnston et al. (1979) proposed numerous mechanisms to explain attenuation (of seismic waves) in rock masses. One of the listed mechanisms, according to Barton (2007), can be extended to major discontinuities, rock boundaries, and faults in tectonic fractured and/or stressed rock masses. Barton strongly supports the idea that seismic $Q$ values provide good insight into rock mass characteristics - where low $Q$ values correspond to poorer, more jointed and more open structures, typical of near surface rocks. Abercrombie (1998) determined that joints and fractures acted as major scatterers of seismic energy. The possible reasons for strong attenuation at a shallow depth can be attributed to high fracture densities at outcrops and the presence of joints at moderate or low pressures. A reduction of seismic attenuation with respect to depth is expected due to a reduction of the number of joints and fractures and greater closure with higher stress. Worthington and Hudson (2000) investigate whether any useful information about a fault can be obtained from attenuation and conclude that relatively high values of attenuation were found in the fault zone. They identified the $Q$ anomaly as a result of certain changes in rock properties.

Belinic et al. (2018) indicated the presence of a boundary area between the thicker lithosphere under the northwestern External Dinarides and the thinned lithosphere under the Lika region. Earlier, Šumanovac et al. (2017) emphasized the existence of the Adriatic slab, which means that a thicker lithosphere must exist: "The fast anomaly is interpreted as a unique Adriatic lithosphere slab sinking underneath the Dinarides, which is considered the primary cause of the formation of the External Dinarides." This anomaly is discovered by the teleseismic tomography and recognized as the ND anomaly (northern Dinaridic fast-velocity anomaly). Interestingly, the ND anomaly in the area of Gorski Kotar (e.g. Šumanovac and Dudjak, 2016; Šumanovac et al., 2017) partly fit the observed $\kappa$ decrease. It could be speculated that the northern Dinaric fast-velocity anomaly (ND anomaly), identified on the teleseismic tomography for the wider Kvarner, may be related to the lithospheric transform zone striking transversally to the Dinarides below the Kvarner area (Korbar, 2009), delineating the boundary between the NW and SE Adriatic microplate fragments recognized by Oldow et al. (2002). If that is the case, the differential movements of the two Adria fragments correspond along crustal faults that evidently have not fully dissected the thin-skinned tectonic cover, given that there is a more or less continuous but bent fold-and-thrust belt in the NW part of the External Dinarides (Placer et al., 2010).

\section{Macroseismic field}

Spatial distribution of macroseismic intensities is generally influenced by major geological and tectonic features (Bot-
Table 4. Basic parameters for the set of earthquakes that were microseismically investigated.

\begin{tabular}{lccclll}
\hline Date & $\begin{array}{c}\text { Time } \\
(\mathrm{GMT})\end{array}$ & $\begin{array}{c}\text { Latitude } \\
\left({ }^{\circ} \mathrm{N}\right)\end{array}$ & $\begin{array}{c}\text { Longitude } \\
\left({ }^{\circ} \mathrm{E}\right)\end{array}$ & $\begin{array}{l}I_{0} \\
{ }^{\circ} \mathrm{MSK}\end{array}$ & $\begin{array}{l}{ }^{\circ} \mathrm{Max} \\
{ }^{\circ} \mathrm{MSK}\end{array}$ & $M_{\mathrm{L}}$ \\
\hline 1 Mar 1870 & $19: 57$ & 45.510 & 14.332 & & VIII & \\
12 Mar 1916 & $03: 23$ & 45.140 & 14.920 & VIII & & 5.8 \\
5 Feb 1939 & $22: 00$ & 45.150 & 14.630 & VI-VII & & 4.6 \\
6 Feb 1939 & $07: 23$ & 45.160 & 14.660 & VI-VII & & 4.9 \\
5 Feb 2007 & $08: 30$ & 45.070 & 14.950 & & VII & 4.9 \\
30 Jul 2013 & $12: 58$ & 45.068 & 15.030 & & VI & 4.8 \\
\hline
\end{tabular}

tari et al., 1984) and, on a smaller scale, by local geological conditions, such as the surface soil, the surface-to-bedrock soil structure in sedimentary basins and the depth of the saturated zone (Seed and Schnabel, 1972). Also, the distribution of macroseismic intensities may reveal the large tectonic features (Besana et al., 1997; Bottari et al., 1984; Hashida et al., 1988; Lekkas, 2001). Study of the macroseismic field can give information about near-surface attenuation of the seismic waves in the frequency range of $0.4-13 \mathrm{~Hz}$ (Sokolov, 2002).

In this paper, macroseismic fields are displayed for the chosen set of six earthquakes (Table 4) with epicentres located in the study area. Earthquakes occurred in the period 1870-2013, and for the majority of the time (in the period before the second half of the 20th century), macroseismic intensities are the only reliable source of information. The magnitude range of the chosen events is 4.7-5.8. The strongest earthquake occurred on 12 March 1916 near Grižane. It was a very strong event, with a maximum intensity $I_{\max }=$ VIII $\cdot$ MSK (Medvedev-Sponheuer-Karnik MSK - scale)

Macroseismic fields (the synthetic isoseismals) are modelled using the SAF (Strong Attenuation at Faults zones) model (Sović and Šariri, 2016; Fig. 8). This model assumes that the active faults attenuate macroseismic intensities; hence, the most important input data are a map of the active faults. For that purpose, the information on faults was taken from the "Map of Active Faults in Croatia" (Ivančić et al., 2006). The synthetic isoseismals (Fig. 8) are compared with the empirical ones by using the image moments analysis method (Sović et al, 2013, 2016; Sović and Šariri, 2018). The results show that synthetic isoseismals present $31.4 \%$ better approximation of the empirical macroseismic field (Sović and Šariri, 2018) than the circular model (von Kövesligethy, 1907). From these results it is evident that fault zones are responsible for a significant part of wave attenuation and for the anisotropy of attenuation. Synthetic isoseismals are similar but not identical to the empirical ones because the wave attenuation at fault zones is only one of the mechanisms which modifies the macroseismic field. The shape of the macroseismic field also depends on the other factors like amplification of the shallow sedimentary layers (Seed et al., 1972), topography (Geli et al., 1988; Buech et al., 2010) and deamplifi- 


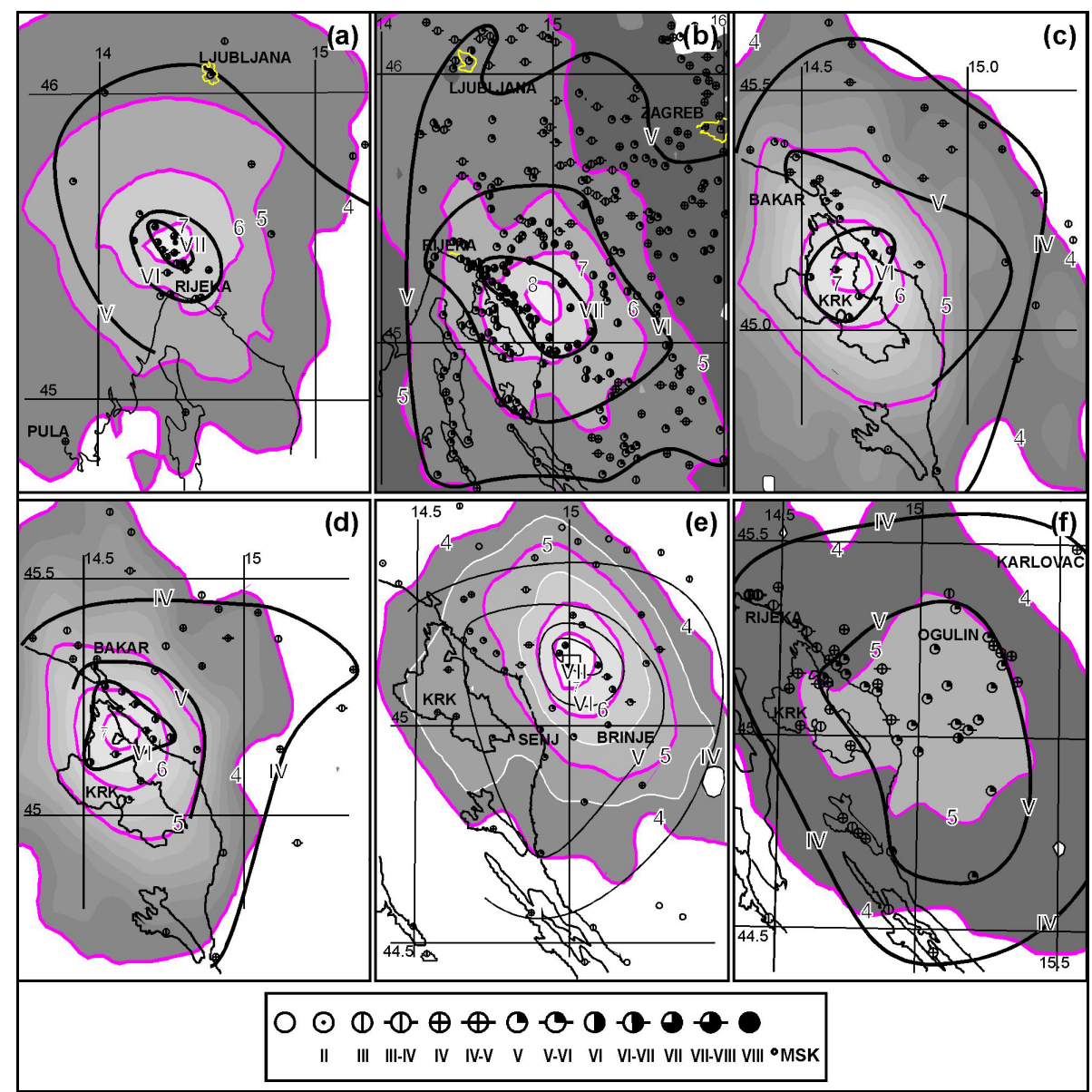

Figure 8. Empirical (black lines) and modelled (purple lines) isoseismal maps for the earthquakes that occurred on (a) 1 March 1870 at 19:57 UTC, (b) 12 March 1913 at 03:23 UTC, (c) 5 February 1939 at 22:00 UTC, (d) 6 February 1939 at 07:23 UTC; (e) 5 February 2007 at 08:30 UTC and (f) 30 July 2013 at 12:58 UTC.

cation due to nonlinear effects (Beresnev and Wen, 1996). Intensity amplification by site effects can be seen in Fig. 8b$\mathrm{f}$, where empirical intensities in deep soil zones NE from the epicentral areas (river valleys in Gorski Kotar, Slovenia and Pannonian basin) are greater than the synthetic ones. The similarity of synthetic and empirical isoseismals in areas with negligible site effects means that the strong attenuation of macroseismic intensity at fault zones is a valid assumption.

Attenuation of macroseismic intensity is a consequence of attenuation of seismic waves caused by a high level of fracturing in fault zones (Gentili and Franceschina, 2011) and temporary decrease in the shear modulus in the fault core under the influence of incoming waves (Johnson and Jia, 2005); thus, the attenuation of macroseismic field can be linked to the parameter $\kappa$ by the same physical mechanisms.

\section{Estimation of near-surface attenuation - summary and conclusions}

The main problem associated with the regional $\kappa$ variation and attenuation and its connection with the geological and tectonic environment at a local and regional level is in a proper definition of the tectonics (deformed or undeformed plates and fault description) and the thickness of the shallow crustal deposits with different geological characteristics at each station's area.

As suggested by Gentili and Franceschina (2011), higher $\kappa$ values can be linked to a high level of fracturing (that characterizes fault zones). The major contribution to the total $\kappa_{0}$ is due to the sedimentary column (from the surface level to a depth of $800 \mathrm{~m}$ ). Furthermore, Campbell (2003) recognized that the scattering effects, due to small-scale heterogeneities in the geological profile beneath the recording stations, may have a significant impact on the final $\kappa$ values.

Based on the calculated $\kappa$ values, the published $Q$ values, empirical and modelled macroseismic fields, and geological 
features of the area of the northwestern External Dinarides and the associated part of the Adriatic foreland, the following can be concluded.

- In the coastal area (Velebit area), near-surface attenuation is lower in the NW-SE direction. To the west, the reduction of attenuation becomes more pronounced in the SW-NE direction (area of the Krk Island); hence, in the southern part of Istria, the lower attenuation is more dominant in a SW-NE direction.

- Given that the modelled macroseismic fields are well matched with empirical data, and also based on observations of near-surface attenuation as defined based on the $\kappa$ parameter, the modelling performed in this paper is applicable when assessing local near-surface attenuation (in the investigated area) under the assumption of a realistic earthquake scenario.

- Regional geological variability is important for estimating near-site attenuation $\kappa_{0}$.

- The values of $V_{\mathrm{s} 30}$ can only be compared with the estimated $\kappa_{0}$ values, and, based on Tables 1 and 2 , the conclusion is that these two values are inversely proportional; $Q$ values calculated from coda waves and those estimated from $\kappa$ values (Table 3 ) are considered to be comparable (subject to certain limitations).

- There is an indistinct correlation between the observed attenuation and the rate of tectonic deformation (tectonic fracturing). The platform carbonates in the thinskinned parts of the fold-and-thrust belt are more fractured, while the carbonates below the major detachments (deformed only by a late-orogenic thick-skinned tectonics) as well as the carbonates in the foreland are less fractured.

- It may be hypothesized that the observed lower attenuation west of the southwestern coast of Istria is caused by S-wave reflection from parts of the Mohorovičić discontinuity at depths below $30 \mathrm{~km}$.

- When taking all this into consideration, the dextral shift of the frontal thrust from the External Dinarides along the Kvarner fault zone, and the deeper position of the $\mathrm{BC}$ horizon east of the zone, has probably had an effect on the geometry of the $\kappa$ parameter contour lines, i.e. observed attenuation in the investigated region.

- It may be speculated that the rather complex tectonic structure and northern Dinaric fast-velocity anomaly (ND anomaly) identified on the teleseismic tomography for the wider Kvarner region is superimposed on the lithospheric decoupling of the NW and SE fragments of the Adriatic microplate.
- The attenuation properties of rocks in the northwestern External Dinarides are far from isotropic. The most likely anisotropy sources are the preferential orientations of cracks and fractures under the local tectonic stress field, trapping of waves along major faults (waveguides), and/or attenuation within the fault zones.

The results presented in this paper are significant for expanding knowledge on attenuation of near-surface crust layers in the similar geological and tectonic settings. Besides this, the results highlight the importance of reliable information on local source model parameters. Furthermore, the use of the SAF model (Sović and Šariri, 2016) based on realistic earthquake scenarios enables prediction of attenuation in specific areas.

Data availability. Data are not publicly accessible. Access to metadata is available upon the request.

Author contributions. SM and DS conceived of the presented idea. SM developed the theoretical formalism. DS performed field measurements, performed the computational framework, and analysed the data. SM encouraged DS to investigate $\kappa$ properties and supervised the findings of this work. TK provided a geological background and interpretation of the results from a geological point of view. IS presented macroseismic data and models. All authors discussed the results. SM took the lead in writing the paper, with great support from DS. The other two authors also contributed to the paper, provided critical feedback, and helped shape the final paper.

Competing interests. The authors declare that they have no conflict of interest.

Acknowledgements. The authors are thankful to Mario Gazdek for geophysical measurements and Ines Ivančić for design of several figures. We also thank to the editor, as well as Franjo Šumanovac and one anonymous reviewer, for the constructive criticism on the submitted version of the paper.

Financial support. This research has been supported by the Croatian Science Foundation (projects HRZZ IP-2016-06-1854 and HRZZ IP-2014-09-9666) and the University of Zagreb, Faculty of Geotechnical Engineering.

Review statement. This paper was edited by Filippos Vallianatos and reviewed by Franjo Šumanovac and one anonymous referee. 


\section{References}

Abercrombie, R. E.: A Summary of Attenuation Measurements from Borehole Recordings of Earthquakes: The $10 \mathrm{~Hz}$ Transition Problem, Pure Appl. Geophys., 153, 475-487, 1998.

Aljinović, B. and Blašković, I.: About the deep seismic horizon in the NE Adriatic area, ZSN JAZU, Proceed. Ser. A8, 1, 363-380, 1981.

Aljinović, B., Blašković, I., Cvijanović, D., Prelogović, E., Skoko, D., and Brdarević, N.: Correlation of geophysical and seismological data in the coastal part of Yugoslavia, Bolletino di Oceanologia Teorica ed Applicata, II, 77-90, 1984.

Anderson, J. G. and Hough, S. E.: A model for the shape of the Fourier amplitude spectrum of acceleration at high frequencies, Bull. Seismol. Soc. Am., 74, 1969-1993, 1984.

Barton, N.: Rock Quality, Seismic Velocity, Attenuation and Anisotropy, Taylor \& Francis Group, London, UK/Balkema, Leiden, the Netherlands, 2006.

Battaglia, M., Murray, M. H., Serpelloni, E., and Bürgmann, R.: The Adriatic region: An independent microplate within the Africa-Eurasia collision zone, Geophys. Res. Lett., 31, 1-4, https://doi.org/10.1029/2004GL019723, 2004.

Belinić, T., Stipčević, J., Živčić, M., and AlpArrayWorking Group: Lithospheric thickness under the Dinarides, Earth Planet. Sc. Lett., 484, 229-240, https://doi.org/10.1016/j.epsl.2017.12.030, 2018.

Beresnev, I. A. and Wen, K. L.: Nonlinear soil response - a reality?, Bull. Seismol. Soc. Am., 86, 1964-1978, 1996.

Besana, G. M., Negishi, H., and Ando, M.: The three-dimensional attenuation structures beneath the Philippine archipelago based on seismic intensity data inversion, Earth Planet. Sc. Lett., 151, 1-11, 1997.

Biro, Y. and Renault, P.: Importance and impact of host-to-target conversions for ground motion prediction equations in PSHA, in: 15th World Conference on Earthquake Engineering, 2428 September 2012, Lisbon, Portugal, 2012.

Boore, D. M.: Stochastic simulation of high-frequency ground motions based on seismological models of the radiated spectra, Bull. Seismol. Soc. Am., 73, 1865-1894, 1983.

Boore, D. M.: Simulation of Ground Motion Using the Stochastic Method, Pure Appl. Geophys., 160, 635-676, https://doi.org/10.1007/PL00012553, 2003.

Boore, D. M. and Joyner, W. B.: Site amplifications for generic rock sites, Bull. Seismol. Soc. Am., 87, 327-341, 1997.

Bottari, A., Federico, B., and Lo Giudice, E.: The correlation between the macroseismic attenuation trend and the geo-structural framework; The Calabro-peloritan Arc an example, Tectonophysics, 108, 33-49, 1984.

Brdarević, N. and Oluić, M.: Contribution to the knowledge of tectonical structure of the Adriatic sea bottom, Rudarsko-geološkonaftni fakultet, Proceedings, Sveučilište u Zagrebu, 318-332, 1979.

Brückl, E., Bleibinhaus, F., Gosar, A., Grad, M., Guterch, A., Hrubcová, P., Keller, G. R., Šumanovac, F., Tiira, T., Yliniemi, J., Hegedûs, E., and Thybo, H.: Crustal structure due to collisional and escape tectonics in the Eastern Alps region based on profiles Alp01 and Alp02 from the ALP 2002 seismic experiment, J. Geophys. Res., 112, B06308, https://doi.org/10.1029/2006JB004687, 2007.
Buech, F., Davies, T. R., and Pettinga, J. R.: The Little Red Hill seismic experimental study: Topografic effects on ground motion at a bedrock-dominated mountain edifice, Bull. Seismol. Soc. Am., 100, 2219-2229, 2010.

Campbell, K. W.: Prediction of strong ground motion using the hybrid empirical method and its use in the development of ground motion (attenuation) relations in eastern North America, Bull. Seismol. Soc. Am., 93, 1012-1033, 2003.

Chandler, A. M., Lam, N. T. K., Tsang, H. H., and Sheikh, M. N.: Estimation of near-surface attenuation in bedrock for analysis of intraplate seismic hazard, J. Seismol. Earthq. Eng., 7, 159-173, 2005.

Dasović, I.: Attenuation of seismic waves beneath the Dinarides, $\mathrm{PhD}$ dissertation, University of Zagreb, Faculty of Science, Zagreb, Croatia, p. 125, 2015.

Dasović, I., Herak, M., and Herak, D.: Attenuation of coda waves in the contact zone between the Dinarides and the Adriatic Microplate, Stud. Geophys. Geodae., 56, 231-247, https://doi.org/10.1007/s11200-010-0077-8, 2012.

Dasović, I., Herak, M., and Herak, D.: Coda-Q and its lapse time dependence analysis in the interaction zone of the Dinarides, the Alps and the Pannonian basin, Phys. Chem. Earth, 63, 47-54, https://doi.org/10.1016/j.pce.2013.03.001, 2013.

Delavaud, E., Cotton, F., Akkar, S., Scherbaum, F., Danciu, L., Beauval, C., Drouet, S., Douglas, J., Basili, R., Sandikkaya, M. A., Segou, M., Faccioli, E., and Theodoulidis, N.: Toward a ground-motion logic tree for probabilistic seismic hazard assessment in Europe, J. Seismol., 16, 451-473, https://doi.org/10.1007/s10950-012-9281-z, 2012.

Del Monaco, F., Tallini, M., De Rose, C., and Durante, F.: HVNSR survey in historical downtown L'Aquila (central Italy): Site resonance properties vs. subsoil model, Eng. Geol., 158, 34-47, https://doi.org/10.1016/j.enggeo.2013.03.008, 2013.

Di Giacomo, D., Gallipoli, M. R., Mucciarelli, M., Parolai, S., and Richwalski, S. M.: Analysis and modeling of HVSR in the presence of a velocity inversion: The case of Venosa, Italy, Bull. Seismol. Soc. Am., 95, 2364-2372, https://doi.org/10.1785/0120040242, 2005.

Drouet, S., Cotton, F., and Guéguen, P.: VS30, $\kappa$, regional attenuation and $\mathrm{Mw}$ from accelerograms: Application to magnitude 3-5 French earthquakes, Geophys. J. Int., 182, 880-898, https://doi.org/10.1111/j.1365-246X.2010.04626.x, 2010.

Đurasek, N., Frank, G., Jenko, K., Kužina, A., and Tončić-Gregl, R.: Prilog poznavanju naftno-geoloških odnosa u sjeverozapadnom dijelu jadranskog podmorja (Contribution to the understanding of oil-geological relations in NW Adriatic area), in: (Proceedings) I Kompleksna naftno-geološka problematika podmorja i priobalnih dijelova Jadranskog mora (Complex Oil-geological Aspects for Offshore and Coastal Adriatic Areas), edited by: Šolc, A., Split, Zbornik radova, 201-213, 1981.

Edwards, B., Fäh, D., and Giardini, D.: Attenuation of seismic shear wave energy in Switzerland, Geophys. J. Int., 185, 967-984, https://doi.org/10.1111/j.1365-246X.2011.04987.x, 2011.

Finetti, I. R. (Ed.): Depth contour Map of the Moho discontinuity in the Central Mediterranean region from new CROP seismic data, in: CROP Project, Deep Seismic Exploration of the Central Mediterranean and Italy, Atlases in Geoscience, chap. 27, Plate 1 (map), edited by: Finetti, I. R., Elsevier, New York, 597-606, 2005. 
Geli, L., Bard, P. Y., and Jullien, B.: The effect of topography on earthquake ground motion: A review and new results, Bull. Seismol. Soc. Am., 81, 42-63, 1988.

Gentili, S. and Franceschina, G.: High frequency attenuation of shear waves in the southeastern Alps and northern Dinarides, Geophys. J. Int., 185, 1393-1416, https://doi.org/10.1111/j.1365-246X.2011.05016.x, 2011.

Gosar, A.: Microtremor HVSR study for assessing site effects in the Bovec basin (NW Slovenia) related to 1998 Mw5.6 and 2004 Mw5.2 earthquakes, Eng. Geol., 91, 178-193, https://doi.org/10.1016/j.enggeo.2007.01.008, 2007.

Gosar, A. and Martinec, M.: Microtremor HVSR study of site effects in the Ilirska Bistrica town area (S. Slovenia), J. Earthq. Eng., 30, 13-50, https://doi.org/10.1080/13632460802212956, 2009.

Gosar, A., Rošer, J., Šket-Mošnikar, B., and Zupančić, P.: Microtremor study of site effects and soil-structure resonance in the city of Ljubljana (central Slovenia), Bull. Earthq. Eng., 8, 571592, https://doi.org/10.1007/s10518-009-9113-x, 2010.

Grad, M., Tiira, T., and ESC Working Group: The Moho depth map of the European Plate, Geophys. J. Int., 176, 279-292, https://doi.org/10.1111/j.1365-246X.2008.03919.x, 2009.

Grandić, S., Biancone, M., and Samaržija, J.: Geophysical and Stratigraphic Evidence of the Adriatic Triassic Rift Structures, Mem. Soc. Geol. It., 57, 315-325, 2002.

Gravity map of Yugoslavia: Gravimetrijska karta SFR Jugoslavije Bouguerove anomalije, $1: 500000$, Federal Geological Institute, Beograd, 1972.

Handy, M. R., Ustaszewski, K., and Kissling, E.: Reconstructing the Alps-Carpathians-Dinarides as a key to understanding switches in the subduction polarity, slab gaps and surface motion, Int. J. Earth Sci., 104, 1-26, https://doi.org/10.1007/s00531-014-10603, 2015.

Hanks, T. C. and McGuire, R. K.: The character of high-frequency strong ground motion, Bull. Seismol. Soc. Am., 71, 2071-2095, 1981.

Hashida, T., Stavrakakis, G., and Shimazaki, K.: Three-dimensional seismic attenuation structure beneath the Aegean region and its tectonic implication, Tectonophysics, 145, 43-54, 1988.

Herak, M.: Overview of recent ambient noise measurements in Croatia in free-field and in buildings, Geofizika, 28, 21-40, 2011.

Herak, M., Herak, D., and Markušić, S.: Revision of the earthquake catalogue and seismicity of Croatia, 1908-1992, Terra Nova, 8, 86-94, 1996.

Herak, M., Allegretti, I., Herak, D., Kuk, K., Kuk, V., Marić, K., Markušić, S., and Stipčević, J.: HVSR of ambient noise in Ston (Croatia): Comparison with theoretical spectra and with the damage distribution after the 1996 Ston-Slano earthquake, Bull. Earthq. Eng., 8, 483-499, https://doi.org/10.1007/s10518009-9121-x, 2010.

HGI: Geološka karta Republike Hrvatske mjerila 1 : 300000 (Geological Map of the Republic of Croatia, scale 1:300000), Hrvatski geološki institut - Croatian Geological Survey, available at: http://webgis.hgi-cgs.hr/gk300/default.aspx (last access: 30 July 2019), 2009.

Ivančić, I., Herak, D., Markušić, S., Sović, I., and Herak, M.: Seismicity of Croatia in the period 2002-2005, Geofizika, 23, 87103, 2006.
Ivančić, I., Herak, D., Herak, M., Allegretti, I., Fiket, T., Kuk, K., Markušić, S., Prevolnik, S., Sović, I., Dasović, I., and Stipčević, J.: Seismicity of Croatia in the period 2006-2015, Geofizika, 35, 69-98, https://doi.org/10.15233/gfz.2018.35.2, 2018.

Johnson, P. A. and Jia, X.: Nonlinear dynamics, granular media and dynamic earthquake triggering, Nature, 437, 871-874, https://doi.org/10.1038/nature04015, 2005.

Johnston, D. H., Toksöz, M. N., and Timur, A.: Attenuation of seismic waves in dry and saturated rocks: II. Mechanisms, Geophysics, 44, 691-711, 1979.

Korbar, T.: Orogenic evolution of the External Dinarides in the NE Adriatic region: a model constrained by tectonostratigraphy of Upper Cretaceous to Paleogene carbonates, Earth Sci. Rev., 96, 296-312, 2009.

Ktenidou, O. J., Gélis, C., and Bonilla, L. F.: A study on the variability of Kappa $(\kappa)$ in a Borehole: Implications of the computation process, Bull. Seismol. Soc. Am., 103, 1048-1068, https://doi.org/10.1785/0120120093, 2013.

Ktenidou, O.-J., Cotton, F., Abrahamson, N. A., and Anderson, J. G.: Taxonomy of $\kappa$ : a review of definitions and estimation approaches targeted to applications, Seismol. Res. Lett., 85, 135146, https://doi.org/10.1785/0220130027, 2014.

Ktenidou, O. J., Abrahamson, N. A., Drouet, S., and Cotton, F.: Understanding the physics of Kappa $(\kappa)$ : Insights from a downhole array, Geophys. J. Int., 203, 678-691, https://doi.org/10.1093/gji/ggv315, 2015.

Kuk, V., Prelogović, E., and Dragičević, I.: Seismotectonically active zones in the Dinarides, Geol. Croat., 53, 295-303, 2000.

Lekkas, E.: The Athenas earthquake (7 September 1999); intensity distribution and controlling factors, Eng. Geol., 59, 297-311, 2001.

Mucciarelli, M. and Gallipoli, M. R.: A critical review of 10 years of microtremor HVSR technique, Bolletino di Geofisica Teorica ed Applicata, 42, 255-266, 2001.

Nakamura, Y.: A method for dynamic characteristics estimation of subsurface using microtremor on the ground surface, Q. Rep. Railway Tech. Res., 30, 25-33, 1989.

Oldow, J. S., Ferranti, L., Lewis, D. S., Campbell, J. K., D’Argenio, B., Catalano, R., Pappone, G., Carmignani, L., Conti, P., and Aiken, C. L. V.: Active fragmentation of Adria, the north African promontory, central Mediterranean region, Geology, 30, 779782, 2002.

Orešković, J., Šumanovac, F., and Hegedûs, E.: Crustal structure beneath Istra peninsula based on receiver function analysis, $\mathrm{Ge}-$ ofizika, 28, 247-263, 2011.

Palenik, D., Matičec, D., Fuček, L., Matoš, B., Herak, M., and Vlahović, I.: Geological and structural setting of the Vinodol Valley (NW Adriatic, Croatia): insights into its tectonic evolution based on structural investigations, Geologia Croatica, 72, 179193, 2019.

Panzera, F., Lombardo, G., D’Amico, S., and Galea, P.: Speedy Techniques to Evaluate Seismic Site Effects in Particular Geomorphologic Conditions: Faults, Cavities, Landslides and Topographic Irregularities, in: chap. 5, InTech, London, 102-138, https://doi.org/10.5772/55439, 2013.

Placer, L., Vrabec, M., and Celarc, B.: The bases for understanding of the NW Dinarides and Istria Peninsula tectonics, Geologija, 53, 55-86, 2010. 
Prelogović, E., Cvijanović, D., Aljinović, B., Kranjec, V., Skoko, D., Blašković, I., and Zagorac, Ž.: Seizmotektonska aktivnost duž priobalnog dijela Jugoslavije, Geološki vjesnik, 35, 195207, 1982.

Reiter, L.: Earthquake Hazard Analysis: Issues and insights, Columbia University Press, New York, p. 254, 1990.

Schmid, S.M., Bernoulli, D., Fügenschuh, B., Matenco, L., Schefer, S., Schuster, R., Tischler, M., and Ustaszewski, K.: The Alps-Carpathians-Dinarides-connection: a correlation of tectonic units, Swiss J. Geosci., 101, 139-183, 2008.

Seed, H. B. and Schnabel, P. B.: Soil and Geological Effects on Site Response During Earthquakes, in: Proc. of First International Conf. on Microzonation for Safer Construction - Research and Application, vol. I, 30 October-3 November 1972, Seattle, Washington, 61-74, 1972.

Sokolov, V.: Seismic intensity and Fourier acceleration spectra: Revised relationship, Earthq. Spect., 18, 161-187, 2002.

Sović, I. and Šariri, K.: Explaining anisotropic macroseismic fields in terms of fault zone attenuation - a simple model, Tectonophysics, 680, 113-121, https://doi.org/10.1016/j.tecto.2016.05.018, 2016.

Sović, I. and Šariri, K.: A simple anisotropic model of macroseismic field, in: 36th General Assembly of the ESC - Book of Abstracts, Valletta, Malta, 2018.

Sović, I., Šariri, K., and Živčić, M.: High frequency microseismic noise as possible earthquake precursor, Res. Geophys., 3, e2, https://doi.org/10.4081/rg.2013.e2, 2013.

Sović, I., Šariri, K., and Tasić, T.: Image processing in macroseismology: use of the image moments analysis for the comparison of isoseismal maps, in: 35th General Assembly of the ESC Book of Abstracts, edited by: Mucciarelli, M., ESC - OGS, Trieste, 2016.

Stanko, D., Markušić, S., Strelec, S., and Gazdek, M.: Seismic response and vulnerability of historical Trakošćan Castle using HVSR method, Environ Earth Sci., 75, 368, https://doi.org/10.1007/s12665-015-5185-x, 2016.

Stanko, D., Markušić, S., Strelec, S., and Gazdek, M.: HVSR analysis of seismic site effects and soil-structure resonance in Varaždin city (North Croatia), Soil Dynam. Earthq. Eng., 92, 666-677, https://doi.org/10.1016/j.soildyn.2016.10.022, 2017.

Šmanovac, F.: Lithosphere structure at the contact of the Adriatic microplate and the Pannonian segment based on the gravity modelling, Tectonophysics, 485, 94-106, https://doi.org/10.1016/j.tecto.2009.12.005, 2010.
Šumanovac, F. and Dudjak, D.: Descending lithosphere slab beneath the Northwest Dinarides from teleseismic tomography, J. Geodynam., 102, 171-184, https://doi.org/10.1016/j.jog.2016.09.007, 2016.

Šumanovac, F., Orešković, J., and Grad, M.: ALP2002 Working Group: Crustal structure at the contact of the Dinarides and Pannonian basin based on 2-D seismic and gravity interpretation of the Alp07 profile in the ALP2002 experiment, Geophys. J. Int., 179, 615-633, https://doi.org/10.1111/j.1365246X.2009.04288.x, 2009.

Šumanovac, F., Hegedûs, E., Orešković, J., Kolar, S., Kovács, A. C., Dudjak, D., and Kovács, I. J.: Passive seismic experiment and receiver functions analysis to determine crustal structure at the contact of the northern Dinarides and southwestern Pannonian Basin, Geophys. J. Int., 205, 1420-1436, https://doi.org/10.1093/gji/ggw101, 2016.

Šumanovac, F., Markušić, S., Engelsfeld, T., Jurković, K., and Orešković, J.: Shallow and deep lithosphere slabs beneath the Dinarides from teleseismic tomography as the result of the Adriatic lithosphere downwelling, Tectonophysics, 712-713, 523541, https://doi.org/10.1016/j.tecto.2017.06.018, 2017.

Tomljenović, B., Csontos, L., Marton, E., and Marton, P.: Tectonic evolution of the northwestern Internal Dinarides as constrained by structures and rotation of Medvednica Mountains, North Croatia, Geol. Soc. Lond. Spec. Publ. 298, 145-167, https://doi.org/10.1144/SP298.8, 2008.

Van Houtte, C., Drouet, S., and Cotton, F.: Analysis of the origins of Kappa $(\kappa)$ to compute hard rock to rock adjustment factors for GMPEs, Bull. Seismol. Soc. Am., 101, 2926-2941, https://doi.org/10.1785/0120100345, 2011.

Velić, I. and Vlahović, I. (Eds.): Explanatory notes for the Geological Map of the Republic of Croatia, scale $1: 300000$, Croatian Geological Survey, Zagreb, p. 147, 2009.

Vlahović, I., Tišljar, J., Velić, I., and Matičec, D.: Evolution of the Adriatic Carbonate Platform: palaeogeography, main events and depositional dynamics, Palaeogeogr. Palaeocl., 220, 333-360, 2005.

von Kövesligethy, R.: Seismischer Stärkegrad und Intensität der Beben, Gerlands Beitrage zur Geophysik, 8, 24-103, 1907.

Worthington, M. H. and Hudson, J. A.: Fault properties from seismic $Q$, Geophys. J. Int., 143, 937-944, 2000.

York, D., Evenson, N., Martinez, M., and Delgado, J.: Unified equations for the slope, intercept, and standard errors of the best straight line, Am. J. Phys., 72, 367-375, 2004. 